\author{
Janez Vodičar* \\ University of Ljubljana, Slovenia
}

\title{
Married Couples' Ministry as a Place of Catechesis
}

\section{Introduction}

The General Directory for Catechesis, in point 258, where it talks about the parish as an environment for catechesis states, "As a solid reference point for parochial catechesis it is necessary to have a nucleus of mature Christians, initiated into the faith, for whom the pastor should have an adequate and differentiated pastoral care. This objective can be more easily achieved by the formation of small

* JANEZ VODIČAR SDB - In 1992 he was ordained a priest and served pastorally in various parishes and pastoral groups. From 1992 to 1996, he was in charge of John Bosco Student Home in Zelimlje. In 2000 he started his doctoral studies at the Theological Faculty of University of Ljubljana with the title Poetics as a Peak or End of Philosophy With the Emphasis on the Search of Speech about God in Paul Ricoeur. He successfully defended the thesis on February 27, 2003. He has been actively involved in the activities of working group of professors of Philosophy. He also wrote extensive introductions to the first translations of works of Paul Ricoeur in Slovenian. With various lectures he has explored the present problems of contemporary humanity, especially of youth. In 2003, he was elected Assistant lecturer and in 2007 Assistant Professor of Didactics of Ethics and Religion at the Theological Faculty of the University of Ljubljana, then in 2011 Associate Professor. He has published articles in many scholarly journals in the fields of hermeneutics, didactics, and religious education and of speech on God. He is now also vice-Dean at the Theological Faculty, an instructor in Gestalt pedagogy and member of EEC (Équipe européenne de catéchèse) or EAK (Europäische Arbeitsgemeinschaft für Katechese) and AIPPh (Association Internationale des Professeurs de Philosophie). 
ecclesial communities"'. The emergence of these small communities in the Catholic Church varies. Most often it is connected to a special Charism or due to a specific environment: such as absence of priests, distance from parish centers, losing sense of belonging to a parish community, etc. In Slovenia, these small communities, which have greatly aided the development of adult catechesis, were formed by the emerging Married Couples' Ministry. These were first formed by a Jesuit, Fr. Vital Vider, S.J., in 1972. This was one of the most innovative and fruitful responses to Vatican Council II in the Slovenian Church ${ }^{2}$. Since then, this movement extended into many organizations, which are spreading, guiding, and connecting different married couples ministries in the spirit of different charismatic or local characteristics.

For a long time, there was not much talk about these ministries. Likewise, they did not receive much attention from the Church. The secular world paid even less attention to them, up until the year 2011, when the debate of changing the family law became the burning issue. The power of married couples ministries in a wider sense, not only in the strictly catechetical sense, was noticeable during the debate over the changes in family law, when these ministries helped influence the public opinion and actively participated in political debates over this question. Through different forums and movements, they did not only achieve the rejection of the proposed law, but they also started a deeper consideration of family values and marriage itself ${ }^{3}$.

Pastoral workers who want to be in sync with the modern world, but at the same time grounded in Christ and Church teaching, cannot overlook the power that family and spouses have on growth in faith and living the life of faith. In his letter to the families, Pope John Paul II stresses, "Throughout this Year it is important to discover anew the many signs of the Church's love and concern for the family, a love and concern expressed from the very beginning of Christianity, when the meaningful term "Domestic Church" was applied to the family. In our own time, we have often returned to the phrase "domestic church", which the council adopted, and the sense of which we hope will always remain alive in people's minds. This desire

1 Congregation for the clergy, General Directory for Catechesis, 258, http://www.vatican.va/ roman_curia/congregations/cclergy/documents/rc_con_ccatheduc_doc_17041998_directory-forcatechesis_en.html (24.08.2013).

2 See I. Platovnjak, Pokoncilski poudarki na področju duhovnosti, “Bogoslovni vestnik" 73 (2013) 2, p. 211 .

3 See http://www.iskreni.net/iskreninet-novice/455-zavod-iskreni-net-o-predlogu-druzinskega-zakonika.html (24.08.2013). 
is not lessened by an awareness of the changed conditions of families in today's world". Many people in the Slovenian Church realize that we must make a step toward families. Only family, no matter what kind, can overcome the duality of the environment with, on one hand, strong traditional roots which have not had a real influence recently, and, on the other hand, an urban environment, where many people are torn out of their routine lives and are isolated. If people, in the past, used the environment as the source of strength for religious life, this support has been lost in the secularized world. Traditionally, religious Christian families are the ones that practice some sort of religious traditions, which have been transmitted from the families of origin. New, modern families lack even this, and are stretched between the expectations of the environment, which is completely secularized, and a personal search for faith ${ }^{5}$. This personal faith can be very different in its source for spouses, and often the easiest compromise for the couple is not to talk about it. In doing that, they are neglecting their own faith and are losing touch with the morals, which are feeding and keeping their Christianity alive ${ }^{6}$.

The Slovenian family, which is supposed to be the primary means of catechesis, left the catechesis of children and youth to the parish community. The parents' passiveness does not only harm children and parish catechesis, but also the married couple itself. Faith, for these families, is something that happens in the church, or at the rectory, and does not have much of an influence on everyday life. That is why it is often up to individual activities or leaders in the parish, whether the youth is connected to the church or not. Making faith personal has become more difficult even for independent adults. It is for this reason that the synod in Slovenia, which

4 John Paul II, Gratissimam Sane, 3, http://www.vatican.va/holy_father/john_paul_ii/letters/ documents/hf_jp-ii_let_02021994_families_en.html (26.08.2013).

5 See A. Stres, Od tradicionalne k osebni vernosti, http://www.druzina.si/icd/spletnastran.nsf/ all/541FF1EA85EF2D43C125790400256212?OpenDocument (26.08.2013): “As far as marriage and family are concerned, (Vinko Potočnik) warns us that "among all European countries, Slovenia has the lowest percentage of marriages". For this reason, the number of Church marriages is also very low, despite the fact that $70 \%$ of first marriages are celebrated as Church weddings. Along with deep crisis of birth rate in Slovenia, lately $52 \%$ of children were born out of wedlock. We are experiencing a deep transformation of family life, which will have a lasting influence on future generations, who will be formed as adults in these families".

6 This phenomenon is not limited to Slovenia; experts in Poland found similar results. See J. Stala and E. Osewska, Sociological aspects of family religious education in Poland, in: E. Osewska, J. Stala (eds.), Religious Education/Catechesis in the Family. A European Perspective, Warszawa 2010, p. 175. 
strived to renew local church at the beginning of the new millennium, stressed this mission, "A rich tradition of faith, which used to serve as a strong foundation for Slovenians in their decision for Christ and for their life after the decision, is today not enough to make the decision and living after the decision is made. Religious traditions, popular devotions, religious literature, and folk art are all aiding the faith, but each person has to make a personal decision, based on their personal experience of God, the message of the Gospel, and their moral stance. Environments, in which people gather experiences from birth, and meet Christ's evangelizers, are primarily family, parish, and other living Church communities ${ }^{7}$. In the eyes of Slovenian Church leadership, family is the foundation for reclaiming the power of faith which can speak to modern man. Married couples ministries are the ones that nurture families in an organized manner, as a good option for adult catechesis and an improved child catechesis.

\section{A Dynamic View of Marriage}

The fact that there is an increased belief in need for pastoral and catechetical work with married couples can be mostly attributed to a different view of marriage after the Second Vatican Council. The Pastoral Constitution on the Church in the Modern World, Gaudium et Spes, is a keystone document which contributed to a different theological understanding of spousal life in pastoral work. "In it we find views that represent a vast shift in understanding of marital union; until then it was mostly understood as a legal contract with a dual purpose - to procreate and raise offspring, and as containment of sexual desires. In the above mentioned constitution, marriage was naturally based on our Creator, which means that it is not a result of human institutions and a human (parliamentary) agreement. /.../ With the council, spouses became part of the called people of God, which affected the understanding of marriage as a sacramental union in vertical as well as horizontal

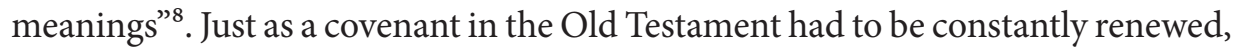
sought, and understood, the marriage-family is supposed to be a place where this same process takes place. "It is interesting that marriage in the perspective of the

7 I. Štuhec, J. Nežič, P. Kvaternik in L. Cvikl, ur., Izberi življenje: sklepni dokument Plenarnega zbora Cerkve na Slovenskem, Ljubljana 2002, Družina, 87.

8 T. Strehovec, Zakonska zveza v perspektivi drugega vatikanskega koncila, "Bogoslovni vestnik" 73 (2013) 2, p. 235. 
council no longer means something static, but something dynamic - the marital relationship has to be nurtured, strengthened and deepened, and must be fed, developed, and encouraged to grow"9.

This dynamic view of marriage is also seen in the teachings of Pope John Paul II. In his apostolic exhortation Familiaris consortio, he writes, "What is needed is a continuous, permanent conversion, which, while requiring an interior detachment from every evil and an adherence to good in its fullness, is brought about concretely in steps which lead us ever forward. Thus a dynamic process develops, one which advances gradually with the progressive integration of the gifts of God and the demands of His definitive and absolute love in the entire personal and social life of man"10. Gradualness, which is recommended by the pope and solidified by the council, is in complete accordance with the pedagogic view of man, who is a developing being. It is also helpful to modern spouses, who are not only facing constant changes in the environment in which they live, but are also entering marriage with a much less solid self-image. A key mission of the family, which comes from this belief, is: "The family, which is founded and given life by love, is a community of persons: of husband and wife, of parents and children, of relatives. Its first task is to live in fidelity, the reality of communion in a constant effort to develop an authentic community of persons" ${ }^{11}$. According to the General Directory for Catechesis it is the family that has a unique advantage of teaching a relationship with God which flows from an experience of human authenticity, "transmitting the Gospel by rooting it in the context of profound human values. On this human base, Christian initiation is more profound: the awakening of the sense of God; the first steps in prayer; education of the moral conscience; formation in the Christian sense of human love, understood as a reflection of the love of God the Father, the Creator" ${ }^{\prime 2}$. Constant searching for this human foundation for the new evangelization is one of the main recommendations of Pope John Paul II in his letter to the families ${ }^{13}$. In Slovenia, the realization of necessity of family ministry

\footnotetext{
9 T. Strehovec, Zakonska zveza v perspektivi drugega vatikanskega koncila, p. 235.

10 John Paul II, Apostolic Exhortation Familiaris Consortio, 9.

11 John Paul II, Apostolic Exhortation Familiaris Consortio, 18.

12 Congregation for the Clergy, General Directory for Catechesis, 255.

13 See Gratissimam Sane, 14: "What is needed then is for human societies, and the families who live within them, often in a context of struggle between the civilization of love and its opposites, to seek their solid foundation in a correct vision of man and of everything which determines the full "realization" of his humanity".
} 
and the power that it has, does not come from the Church teaching and long term plans alone, but mostly from good experiences in the past. Work and life in the parish is showing to be contingent on small communities formed through married couples ministries. At the same time, it is the parents of these families that are the driving force of Catholic education. Most children, who grow up in these families, get involved in one way or another in activities of their local and wider church. Through this, they are becoming the new transmitters of tradition, because the relationships the children formed, while spending time together because of their parents, who were connected through Married Couples' Ministry, is carried on to the next generation. Considering the increased importance of continuous growth of community, which is, through a dynamic understanding of marriage, more open to teaching and learning, pastoral work has shifted from being a method of teaching to a method of joint search for faith. In the process, the doctrinal aspect is not neglected, but it is enriched and placed in a concrete experience of life in faith, which is the ideal environment for catechesis, because the dynamics of marriage fully reflect the dynamic relationship with God.

\section{Married Couples' Ministry as a Path to Keystone Communities}

The council gives clear instructions for connecting married couples, "To facilitate the attainment of the goals of their apostolate, it can be useful for families to be brought together into groups"14. However, connecting couples into a community is not a simple pastoral task. It includes various challenges for the pastoral worker, especially with differences amongst families, their lifestyles, and requirements of modern life. But if anything is certain, it is that community is not a goal but a path, and this is also true for married couples ministries; it is a process through which everybody grows - the pastoral worker, the married couples, and everyone who lives with them ${ }^{15}$.

Therefore, it is not surprising that a movement Najina pot (Our Path) sprung from the original married couples ministries, which were started by Fr. Vital Vider,

14 Decree on the apostolate of the laity, Apostolicam Actuositatem, 11, http://www.vatican. va/archive/hist_councils/ii_vatican_council/documents/vat-ii_decree_19651118_apostolicamactuositatem_en.html (25.08.2013).

15 J. Bajzek, Od skupine k skupnosti, Ljubljana 1997, Inštitut Antona Trstenjaka za psihologijo, logoterapijo in antropohigieno, p. 266. 
S.J. The emphasis is on dual form and on the path. It is first about the spouses, and only then can we start talking about the family. This is how they introduce themselves on their website, "Many young people want to build a complementary marital union, which will serve as a foundation for a strong and healthy family. But 'wanting' does not always mean 'knowing how', which is why too many marriages end up in a vicious cycle, in which they do not know how to bring to fruition what they desired. They got lost in chains of tiredness, lack of attention, stubbornness, blaming each other, and growing further apart, which seems never-ending. However, in their marriage, they could be creating a warm safe haven and a pleasant home for each other. For this reason they live with a sense of deprivation and constant dissatisfaction. Due to such a relationship, children suffer as well, because of their high sensitivity to the relationship between the parents. In an unsettled marriage, children are left without the sense of warmth, safety, and acceptance"16. The first emphasis is obviously completely human. Marriage is a good enough reason to be the starting point of the presentation and the purpose of the work with married couples. It is only after the human dimension is fulfilled, which is what Church documents confirm, that we can talk about a safe home for children as well. Goals that are later presented are much clearer, "Married Couples' Ministry is a place of meeting and making friends for couples who wish to foster and develop their marriage. The first goal of a Married Couples' Ministry is support for the couple, in order to help them be a successful couple, i.e. to keep developing. From this development come all other things: successful parenthood, better functioning in society, and higher involvement in the parish"17. Only now do they talk about involvement in the church, which, according to Najina pot movement, springs from the above mentioned dynamic view of marriage. Everything flows from a marriage, in which each moment becomes a path to see God in each other. It is an authentic and basic catechesis, which makes the family a stem cell of the Church.

Despite this basic anthropological, theological, and pastoral disposition, they did not forget to introduce practical goals for spouses, "We, as couples who visit Married Couples' Ministry receive help to 'learn' how to carry out what we 'wanted'. The first goal of connecting in a married couples ministry is to be the best married couple possible - to be able to live in a way that they wanted and desired. Many married couples who participated in Married Couples' Ministry learned how to talk to each other because of the talking that we have to do as preparation for the

16 http://najina-pot.rkc.si/index.php/content/display/5/zakonske-skupine/ 20 (28.08.2013).

17 http://najina-pot.rkc.si/index.php/content/display/5/zakonske-skupine/ 20 (28.08.2013). 
couples sessions. Most people have no problem talking about current events and actual things. However, many people have a difficult time talking about experiences, emotions, and their inner world. This is just what spouses need to talk about if they want to maintain inner connection and closeness" ${ }^{18}$. Included in this are moments of faith, especially because it spreads from life for life. It is an authentic, catechetical attitude for spouses as well as children. "Only on the basis of everyday faith experiences, may parents start to talk with children about God using correct, interesting and rather simple words"19.

Despite this focus on oneself, on one's own family and ministry, there are monthly meetings where they offer experiences, questions, thoughts about a specific topic, Gospel passage or a current event, which the spouses spent the whole month discussing at home. The purpose of this is much wider, "Couples from our Married Couples' Ministry are not a closed community who do not care about the world events. Better spouses make better parents, better co-workers, and better parishioners. Thus, many couples from our ministries are actively involved in their respective parishes in various ways. They are organists, church choir members, lectors, leaders for marriage preparation and younger married couples ministries, lecturers at marriage preparation retreats, etc." ${ }^{20}$.

Married Couples' Ministry is faithful to the basic belief that the parish is the primary and basic community for families. We can talk about a community of families when the parish grows to a point when families start taking care of other families $^{21}$. A parish community, through Married Couples' Ministry, has become a place for community celebrations, socializing, and help. This is the fulfilment of the basic goal of calling the family a Domestic Church, and leads to the goal that was set by the General Directory for Catechesis, quoted above. With regard to plans and aspirations, we can say that Married Couples' Ministry do not only present a place for catechesis, but are increasingly becoming the means of catechesis, which is, in the end, the only real goal of teaching and learning about faith in the incarnate God.

18 http://najina-pot.rkc.si/index.php/content/display/5/zakonske-skupine/20 (28.08.2013).

19 H. Lombaerts and E. Osewska, Family catechesis/religious education in 21st century Europe, in: E. Osewska, J. Stala (eds.), Religious Education/Catechesis in the Family. A European Perspective, Warszawa 2010, p. 36.

$20 \mathrm{http} / /$ najina-pot.rkc.si/index.php/content/display/5/zakonske-skupine/20 (28.08.2013).

21 See R. Valenčič, Pastorala na razpotjih časa, Ljubljana 2006, Družina, p. 160. 


\section{Organization of Pastoral Work for Married Couples and Families in Slovenia}

There are committees and offices for the family on a diocesan level. In all diocesan offices, except for Celje, groups for marriage preparation can be found; the dioceses of Ljubljana, Maribor, Novo Mesto, and Murska Sobota also organize meetings for married couples, or provide information of already existing ministries,. However, these kinds of ministries do not exist on a diocesan level in Celje and Koper. The field of marriage preparation and Married Couples' Ministry is covered more extensively on deanery and parish levels; examples of married couples ministries that are not necessary dependent on a parish are Družina in življenje (Family and Life) society and the above mentioned Najina Pot movement. On a diocesan level, in the diocese of Murska Sobota, a meeting for married couples and their families in Kančevci was organized this year. The Archdiocese of Ljubljana also organized a families' pilgrimage to Gornji Grad this year. In February there was a national families' pilgrimage to Brezje, where archbishop Msgr. Dr. Anton Stres celebrated a Mass for families. Bishops often talk about families in their addresses, while the actual building of communities for families is taken on by already existing movements and ministries. Therefore, connecting families mostly depends on the participation of leaders of movements, societies and ministries, with their dioceses and diocesan offices for family.

Aside from these official organizations which nurture married couples and families, families mostly participate in different movements and associations, which are developing on their own and are involved in family ministry. Their primary mission is the communal renewal of parishes, living according to the Gospel and Christian morals, and to be a light and salt for other families. One of the first movements that, through their work for a wider renewal in the spirit of Jesus Christ, greatly attributed to work for married couples and families is Marijino delo (Mary's Work) or the Focolare movement. This movement connects various families around the world, young and old, priests, religious sisters and brothers with the desire to unify the world and renew family as the primary cell of society. The founder of the movement, Chiara Lubich, upon realizing that God is love, saw this as ideal lifestyle and started inviting others in this kind of life. Thus members of the movement Marijino delo strive to live out love in everyday life. Their work with married couples and families falls under the umbrella called Nova družina (New Family). "The way of life of the movement Nova družina is rooted in the Gospel, and is lived out in their marriages, childrearing, in creative dialogue with other families, and along with them, in different cultural activities - social as well 
as religious - in their environment" ${ }^{\text {22 }}$. Their ecumenical and interfaith dimension and openness also sets them apart from other movements and associations.

The oldest movement, established exclusively to support married couples, is the above mentioned organization Najina pot. It was founded in 1970, when Fr. Vital Vider, S.J. first organized a married couples' retreat. Two years later, the first ministries started forming, and by last year included 56 ministries with 422 couples. If we just take a look at the number of family members who are included in this movement, we can easily understand how important this movement has been for Slovenia. Aside from the couples, there are 1283 children included, which represents an above-average birth rate for Slovenia. This movement, fueled by Ignatian spirituality, is typically marked by a distinctive and well developed method, and a great emphasis on marriage preparation, which prepares young couples for marriage for a whole year or even longer before their wedding. They present this preparation with broad anthropological goals, but do not hide their Christian foundations, "Years of experience in working with married couples show that it is necessary to let young couples know what they are likely to experience in marriage in family well before their wedding. Thus, prepared and warned, they are much more capable of reacting wisely and maturely to the problems when these arise"23.

Družina in življenje association was founded by a married couple - Dani and Vilma Siter - who have been dedicating all their time to married couples and families for a few years now. Besides regular seminars and meetings for married couples, the association organizes a week-long families' retreat, and also pilgrimages. The goal of the association is primarily to bring families together and support them in today's world. In the year 2012, their association included 120 married couples ministries, which comprised around 740 couples. They develop their own program, publish their own magazine, and train leaders to lead the ministries. Their mission statement clearly shows that their married couples' ministry is providing a place to learn and grow, "For those of us who meet in Married Couples' Ministry, they serve as a sort of 'school environment'; we could call them 'educational facilities' - 'classrooms'. In the ministry, couples learn from each other and from the materials that we use (we have materials that could be called 'Lesson plans for Married Couples' Ministry). Most of the materials deal with our relationship - it explains the dynamics and

22 http://www.gibanjefokolarov.si/druzine (29.08.2013).

$23 \mathrm{http}: / /$ najina-pot.rkc.si/index.php/content/display/4/sola-za-zakon/20 (29.08.2013). 
dimensions of our relationship, warns us about the traps and dangers that spouses face during their life together"24.

As an answer to an increased emphasis on internet communication, a movement Iskreni.net (Honest.net) was born. The name itself reveals its intentions: using the internet to encourage more honesty and depth in a couple's relationship. Iskreni. net institution is the most prolific member of the media in the field of the family. The founders of the institution want to use Christian morals to spread the beauty of family life. The institution offers various programs for couples who are preparing for marriage, already married couples, and also for parents. They have a special class for them. One of the biggest, most noticeable events that the institution prepares is the so-called Festival družin (Festival of Families), which is organized on the international family day (May $15^{\text {th }}$ ), where thousands of children and parents are gathered for fellowship and is always linked to the Eucharist. With their more 'technologicall' and open approach they are reaching younger married couples, because the anonymity of the media helps them with taking on their roles as a couple and in the family ${ }^{25}$. They are launching a new website iskreniPlus.si (honestPlus.si) on the $1^{\text {st }}$ September, which will be the leading Catholic web platform for personal, marital, and parental growth.

Supporting and encouraging numerous families is a foundation called Anin sklad (Ana's fund). Anin sklad, which was founded by the Conference of Religious Orders in Slovenia, is meant mainly for families with multiple children, or those who wish to have one. While it mostly offers financial help, it is also meant for the spiritual growth of the family. Since the public opinion is unfavorable to large families the movement functions as a sort of catechesis for the Slovenian public, to teach them about openness to and the joy of life. They meet multiple times each year, and the fund already covers 374 families $^{26}$.

Lately, the Emmanuel movement started targeting their work at married couples and families; with their focus on evangelization, they provide for couples who are able to fully witness for Christ, and thus present married life as a possible catechesis to other people. "Couples open their spousal and family life to God - they invite him to visit, enlighten, and renew it from all aspects. This connectedness to God, which is practiced mainly through prayer, communal life, and adoration, is a constant encouragement for an open dialogue, offering oneself in the intimacy of life, true

\footnotetext{
24 http://www.diz.si/zakonske-skupine/pridru\%C5\%BEite-se-nam (29.08.2013).

25 See http://iskreni.net/ (29.08.2013).

26 See http://anin-sklad.rkc.si/index.php (29.08.2013).
} 
parental responsibility and ability to forgive each other. Married couples, through their humble everyday life, experience God's proximity, how he takes on their human worries, and how they cannot achieve anything or become truly fruitful without him"27. Many find that the experiences of faith, adoration, witnessing, and charity becomes their path to a better marital life.

Besides these nation-wide Slovenian organizations of married couples' ministries there are many independent ministries that are active in their parishes. These are usually started by a couple who had an experience of one of the above mentioned ministries, or by an experienced priest who desires to work with married couples. In order to have a healthy parish community, it is evident that there needs to be an active married couples ministry, or another form of connecting families. The parish has to value these ministries and their work, by educating the community in an "intentional, gradual, active, and constant (fulfilling) way"28.

\section{Conclusion: Plans and Expectations of the Slovenian Church for Married Couples and Families}

The key document, the Pastoral Plan for Slovenia ${ }^{29}$, which was presented last year, offers some guidance and encouragement for married couples' ministries and family life. The main thrust is to move from the traditional to the personal faith in the Triune God, with the help of receiving of sacraments regularly, especially the Eucharist and Reconciliation, reading the Bible, and personal and family prayer. This will help the faith grow beyond just a formal belonging to Catholicism. Personal faith therefore calls for a living community, which should be seen in family life as praying for each other, and conversations between the spouses and the entire family. For this reason, the Slovenian synod, on the verge of the new millennium, encouraged renewal of catechesis for adults as well as parents, and children ${ }^{30}$; pastoral work was shown, by the resulting document, as practical steps towards a group catechesis for parents and children, especially during sacramental preparation,

27 See http://www.skupnost-emanuel.si/skupen-klic/pari-in-druzine/ (30.08.2013).

28 R. Valenčič, Osnove pastoralne teologije, Ljubljana 2010, Družina, p. 133.

29 See Slovenska škofovska konferenca, Pridite in poglejte, Celje - Ljubljana 2012, Mohorjeva družba.

30 See I. Štuhec, J. Nežič, P. Kvaternik and L. Cvikl, (eds.), Izberi življenje: sklepni dokument Plenarnega zbora Cerkve na Slovenskem, Ljubljana 2002, Družina, 349. 
where the cut-off is no longer physical age, but personal maturity ${ }^{31}$. Even though the official pastoral catechesis is still tied to the organized receiving of the sacraments, church leadership has become aware of the weaknesses of this kind of approach, which makes them open to new approaches, especially through married couples ministries. We notice that even in the light of the established catechesis, married couples ministries and family groups have become the center of pastoral work and the means of basic catechetical goals.

We cannot be surprised that this main document lauds newly established or expanded lay groups and movements, which include married couples ministries. These are meant to get a lease of enthusiasm and encouragement with the new pastoral plan. The pastoral plan is still based on the old organization of a parish, because it bases its development and work of marriage and family communities on the basis of local connectedness. Key moments to emphasise the importance of married couples' ministries are still to be found in parishes that are too large. Despite all that, one can still sense a fundamental shift in the pastoral-catechetical approach, "Groups, on one hand, enable personal encounter of Christ and brothers and sisters, and on the other hand, they are a laboratory and an engine for wider work in society and church" ${ }^{32}$. From these goals we can deduce that it is more than just an adaptation of former exclusive parish ministry. A personal encounter of Christ has become strongly connected with a practical experience of life, especially in a relationship with others. Marriage and family are not simply examples of where this is the most obvious, but they reflect Revelation most accurately. This interpretation is not specific to Slovenia; it is generally accepted elsewhere as well ${ }^{33}$. Thus, the pastoral plan agrees with the whole new theological direction of the Church in relation to married couples: that they represent the fundamental place for an experience and growth in faith. The Church thus becomes a community which is more alive, one that is constantly establishing a relationship with God. This is the real goal of catechesis. We can deduce that it is married couples' ministries, with their life and work, which have become catechists of the modern Church. With their work on relationships and faith, married couples' groups have entered the

31 See Slovenska škofovska konferenca, Pridite in poglejte, Celje - Ljubljana 2012, Mohorjeva družba, p. 41.

32 See Slovenska škofovska konferenca, Pridite in poglejte, p. 32.

33 See J. Stala, Familienkatechese in Polen um die Jahrhundertwende. Probleme und Herausforderungen, Tarnow 2008, Biblos, p. 69. 
path of evangelization with the help of Incarnation. They are rooted in real life and God is revealing himself to them in the midst of everyday life as the God of love.

\section{Bibliography}

Bajzek J., Od skupine k skupnosti, Ljubljana 1997, Inštitut Antona Trstenjaka za psihologijo, logoterapijo in antropohigieno.

Congregation for the clergy, General Directory for Catechesis, http://www.vatican.va/ roman_curia/congregations/cclergy/documents/rc_con_ccatheduc_doc_17041998_directoryfor-catechesis_en.html (24.08.2013).

Decree on the apostolate of the laity, Apostolicam Actuositatem, http://www.vatican.va/archive/ hist_councils/ii_vatican_council/documents/vat-ii_decree_19651118_apostolicamactuositatem_en.html (25.08.2013).

John Paul II, Apostolic Exhortation Familiaris Consorti, http://www.vatican.va/holy_father/ john_paul_ii/apost_exhortations/documents/hf_jp-ii_exh_19811122_familiaris-consortio_en.html (28.08.2013).

John Paul II, Letter for families Gratissimam sane, http://www.vatican.va/holy_father/john_paul_ii/ letters/documents/hf_jp-ii_let_02021994_families_en.html (26.08.2013).

Lombaerts H. and Osewska E., Family catechesis/religious education in 21st century Europe, in: E. Osewska, J. Stala (eds.), Religious Education/Catechesis in the Family. A European Perspective, Warszawa 2010.

Platovnjak I., Pokoncilski poudarki na področju duhovnosti, “Bogoslovni vestnik” 73 (2013) 2, p. 205-213.

Stala J., Familienkatechese in Polen um die Jahrhundertwende. Probleme und Herausforderungen, Tarnow 2008, Biblos.

Stala J. and Osewska E., Sociological aspects of family religious education in Poland, in: E. Osewska, J. Stala (eds.), Religious Education/Catechesis in the Family. A European Perspective, Warszawa 2010, UKSW, p. 167-177.

Slovenska škofovska konferenca, Pridite in poglejte, Celje - Ljubljana 2012, Mohorjeva družba.

Strehovec T., Zakonska zveza v perspektivi drugega vatikanskega koncila, "Bogoslovni vestnik" 73 (2013) 2, p. 223-240.

Stres A., Od tradicionalne $k$ osebni vernosti, http://www.druzina.si/icd/spletnastran.nsf/all/541 FF1EA85EF2D43C125790400256212?OpenDocument (26.08.2013).

Štuhec I., Nežič J., Kvaternik P. and Cvikl L., (eds.), Izberi življenje: sklepni dokument Plenarnega zbora Cerkve na Slovenskem, Ljubljana 2002, Družina.

Valenčič R., Pastorala na razpotjih časa, Ljubljana 2006, Družina.

Valenčič R., Osnove pastoralne teologije, Ljubljana 2010, Družina. 